\title{
Governance and Funding of Universities in the European Higher Education Area: Times of Rupture
}

\author{
Liviu Matei
}

There are notable episodes of "soul-searching" in the history of higher education. One such moment was around the turn of the third millennium in Europe, when the project of a European Higher Education Area (EHEA) was launched. ${ }^{1}$ Those were times of sweeping, mainly positive changes, economically and politically. Europe appeared to be transitioning into a new era: the process of European integration was accelerating through the enlargement of the European Union, supported by quite widespread public enthusiasm; the progress of liberal democracy seemed fast and unstoppable almost everywhere on the continent; the economic outlook was better than ever - to the point that the heads of state and government of the then-EU member countries proclaimed in 2000 that, by building a knowledge society, there will be full employment in the Union in a matter of just a few years (European Union 2000).

In this climate, a broad public policy discussion about the role of the universities (and higher education institutions, more generally) emerged. Fundamentally, it focused on the question how should higher education institutions contribute to newly anticipated, some even planned, changes in the society at large in Europe. A part of the discussion was about the very role or mission of the universities: what

\footnotetext{
${ }^{1}$ The Bologna Process, launched with the Bologna Declaration of 1999, is a voluntary intergovernmental process in higher education based on jointly agreed principles, objectives and standards. Currently, there are 48 European states implementing the Bologna Process, which constitute geographically the European Higher Education Area (EHEA). EHEA, formally launched in 2010 as the common European space for higher education, is considered a result of the Bologna Process.
}

L. Matei $(\bowtie)$

Central European University, Budapest, Hungary

e-mail: mateil@ceu.edu

(C) The Author(s) 2018

A. Curaj et al. (eds.), European Higher Education Area: The Impact of Past and Future Policies, https://doi.org/10.1007/978-3-319-77407-7_35 
are, or rather what should they be for in these times of extraordinary historical changes? Another part, however, was more specifically about how universities should be organised and directed in order to fulfil their (new) role, about what is usually called, in the language of higher education policy, governance and steering tools (including funding, in particular). This policy discussion, in turn, led to action at the European and the national level, reflected in the elaboration and implementation of new models of governance and steering tools, as it will be discussed in this chapter.

Fewer than 20 years after this transformational moment, we are again traversing a period that incites reflection about the role of the universities and the ways to organise and direct them. We are witnessing once again changes of epic dimensions in the economy, politics and ideologies, geopolitics and demography. As it will be discussed in this chapter, these are different changes than in the early years of the millennium and this time the mood is grim. These changes include a regression of democracy in many countries; economic difficulties, more recent or persisting from the financial crisis of 2007-2008; a refugee crisis of unprecedented proportions; a stalled if not reversed European integration process; the corrosion of powerful public policy narratives that were at work in the early years of the millennium (e.g. knowledge society, European integration, democratic development); and the emergence of new or recycled inauspicious ideologies, such as populism and nationalism.

When the external environment turns turbulent in times of major societal transformations, we see universities and other important higher education stakeholders go "soul-searching". The language of soul-searching is a signpost of potentially decades-long changes of directions in higher education, most often arising as a result of pressure from outside the sector. As we are now traversing another era of turbulence, will we see the same "soul-searching" language and can that help signpost for us that there could be large shifts once again in higher education policy? How exactly will current transformations and policy discussions surrounding them influence governance? Will policymakers question the prominent role of the University and the "centrality" it has acquired in Europe in the last two-three decades?

The present volume looks at the state of affairs in the EHEA, in search of insight and recommendations for the summit of the ministers in charge of higher education of the EHEA countries to be held in 2018. The section introduced by the present chapter looks specifically into the situation in the area of governance and funding.

As a thematic background paper, the present chapter takes the view that the extraordinary "soul" language about higher education is used in turbulent times, as we are seeing currently in Europe. This language signposts the concerns in the broader public policy arena for the mission ("soul") of the universities and helps identify and understand the attempts to define new expectations and prescriptions about the organisation and direction of the universities that would be fit for such stormy times. 


\section{Governance and Funding as Matters of Concern for Public Policy in the European Higher Education Area (EHEA)}

Governance is currently a prominent matter of concern for higher education policy in the EHEA. It is also a central topic in the scholarship of higher education. The current volume is a good case in point: there are papers focusing on governance in all its sections, not only the one specifically dedicated to this topic. Governance is the cross-cutting theme of this volume. To understand why governance is such a central matter in higher education and public policy, we need to take a broader look at the current state of higher education in Europe, the narratives around governance in higher education and the relationship with external changes in society.

Governance and funding are secular concepts (money, in particular, is an eminently profane entity everywhere!). Surprisingly, the two concepts are sometimes discussed in ways and contexts that appear influenced by theological perspectives and vocabulary. Such is the case when scholars and policymakers talk about the "soul of the university". Most often, they do so to explain, if not lament, that universities have "lost their soul" or to ask that they "regain their soul" and put their work and efforts at the service of new major causes or projects. This language appears to occur in moments of vast and purportedly irrevocable changes that are perceived to have just taken place or are expected to happen in the world around the universities, which justifies the dramatic tone of the discourse, occasionally bordering the eschatological.

Other than the language itself, we may argue there is nothing theological here. The "soul of the university" is a metaphor used by policymakers and scholars (sometimes university leaders, too) when they wish to make important points about the mission, role, or purpose of the university in times of change. The phrase is used because it has a strong, dramatic rhetorical resonance, which might, in fact, be quite fit for exceptional historic situations or policy endeavours. Moreover, the use of this language is, at least in part, more precisely about how universities need to organise and direct themselves or need to be organised and directed from the outside, in order to answer prodigious changes in the society, if not promote change themselves.

In any times of massive changes, we should not be surprised to hear talk about the soul of the university, about its salvation, renaissance or rebirth, and underneath or next to that a lot of talk about university governance and steering tools, such as funding. The current times in the EHEA are such times.

Have the European universities lost their soul, though? Do they need to regain it? Why? Is anybody saying that? What does governance of higher education have to do with this? Why is there so much talk - and also reform action - at present in Europe and the EHEA about university governance? Before we try to answer these questions, it might be useful to illustrate recent instances when this type of language occurred in Europe and elsewhere. This helps sketch a useful analytical framework for when looking into the answers. 
In the U.S., for example, while the focus on research and excellence has been criticised for a long time by a faction of scholars, policymakers and other interested parties (Grubb and Lazerson 2004), recently it has been described as a case of universities simply losing their souls. The immediate context for this assessment is the perception that current transformations in higher education, in matters of cost and access, for example, but also with regard to the very structure of higher education, are momentous and troubling enough to be defined as a crisis. Docking and Curton (2015) wrote a book on this crisis, very fittingly published in a series on "Transformations in Higher Education" and presenting a plan to "save" the small U. S. liberal college. In another recent book, a former Dean of the Harvard College deplores the fact that the great American universities achieve excellence, true, but do it "without a soul", neglecting their core mission, which, at least at undergraduate level, it is stated should be education of the youth (turn young people into adults who will take responsibility for society), rather than the production and perpetuation of knowledge (Lewis 2006).

On another continent and in the context of a completely different crisis and attempt to promote earth-shattering transformations to address it, the South African President Thabo Mbeki (who previously served as Vice-President under Nelson Mandela) drafted the blueprint of a continental-wide project of "African renaissance". When he first presented publicly the project, President Mbeki explicitly places a lot of responsibility on the university for the success of this visionary political undertaking. More specifically, he talks about the need for the African universities to "regain their soul", or otherwise the entire project - and with it the African continent, are at risk:

I would suggest that the entire continent remains at risk until the African university, in the context of the continental reawakening, regains its soul. (Mbeki 2004a, reprinted in almost exactly the same words in Mbeki 2004b, p. 1)

A similar language was used in Europe around the time when the project of a European Higher Education Area was nascent. The European Commission, usually considered as an uncompromising bureaucratic political institution that avoids anything religious, also uses theological-sounding language invoking salvation and redemption as part of its modernisation agenda for higher education, ${ }^{2}$ an otherwise fully secular policy endeavour. The Commission argues in one of the most important documents outlining the parameters of this reform agenda that the EU Member States:

need to create the necessary conditions to enable universities to improve their performance, to modernise themselves and to become more competitive - in short, to become leaders in their own renaissance and to play their part in the creation of the knowledge-based society envisaged under the Lisbon Strategy. (European Union 2006, p. 4)

\footnotetext{
${ }^{2}$ https://ec.europa.eu/education/news/20170622-commission-new-agenda-higher-education_en. Accessed on 5 January 2018.
} 
The document goes on to talk about autonomy — an aspect of governance-and adequate funding - the level of funding as well as funding policies and regulationsas conditions for universities to be able to "regain their souls", become "masters of their own renaissance" and make a contribution to another ambitious project of continental scope: building a European knowledge society, which is planned, under the Lisbon strategy of the European Union, to be the most socially and economically advanced in the world (Matei 2015). Beyond the obvious rhetorical inflection, however, the focus of this type of discourse is not on elusive notions such as soul or salvation, but on mundane, although exceptionally ambitious, policy objectives and tools to achieve them (including governance and funding). This document is a relatively early one in a series that has accompanied the efforts of the EU Commission to promote sweeping economic, political, social and cultural objectives in the EU and larger Europe, using higher education itself, broadly understood, as a tool and assuming that governance and funding are more particular tools within higher education and higher education policy to achieve such objectives.

The talk about the soul of the university is a talk about its mission in special times, or vis-à-vis special, far-reaching political and policy endeavours. Importantly, it is also a talk about governance of higher education in times of major changes, about how universities and higher education systems should be organised and directed so that they pursue a new mission or role, defined in relation to new political or societal ambitions. It was the case in Europe in the early 2000s when the projects of the European Higher Education Area and of European Research Area started. $^{3}$ It is again the case currently, although today's changes are different, in some way even going in the opposite direction compared to those of the early 2000s.

\section{Current Evolutions in Europe: The Impact on Governance and Funding}

Noticeable current developments in Europe outside higher education affect its course and will influence its future. This has always been the case, of course. Except that the current period is not just one of business as usual. We are living once again in times of significant change, rupture and junction points feeding into new trajectories.

We cannot analyse and understand the present state of higher education in Europe and gauge its future unless we acknowledge and try to understand the broader historical evolutions we are living through. In such an effort, it would be an misleading to concentrate on just some kind of technical scrutiny of what is going on within higher education itself, be it in governance or other areas. That is because

\footnotetext{
${ }^{3}$ The European Research Area (ERA) emerged at about the same time with EHEA as a particular initiative under the Lisbon Agenda, EU's overarching strategy between 2000 and 2010.
} 
times are changing - and not from within higher education itself. There is still a lot that is continuing from former times, there is some degree of stability, even inertia, and that must be acknowledged and studied as well. For example, while several countries in the East appear to have lost faith in the idea of the knowledge society as a tool for a better future, most countries in the West still bet on it (Matei 2015); populism helps win elections in many countries of the continent, but not all.

Looking back into the last 15-20 years, one can notice that broader aspirations and processes, beyond the sector itself, helped higher education become "central to the European experience", to borrow a phrase from Scott (1998). Higher education, in particular through the Bologna Process (started in 1999 and leading to the establishment of the European Higher Education Area in 2010) and the Lisbon Strategy of the EU (2000-2010, continued with Europe 2020 strategy after 2010), became a key tool to advance the European construction. European politicians and also, at least to some extent, the European public bet on higher education and transformational initiatives in higher education, such as the Bologna Process, not simply to promote internal reforms here and there, but actually to help build an integrated Europe, economically and politically, a European ethos and perhaps a European demos as well (Matei 2015). It can be stated that those politicians and policymakers who supported Bologna did so not because they were interested that much in higher education but because they were interested in Europe and in the promise that a better integrated and more advanced Europe would help promote economic and social development (including better employment). Higher education became a tool of choice for achieving this vision of Europe. The European Union institutions, mainly the EU Commission, supported higher education forcefully not only at the discourse level but through active initiatives, policies, regulations and funding, in particular after the adoption of the Lisbon strategy. Here too, higher education was not an objective in itself, but a tool, as indicated above in the quote about the role of universities in building a European knowledge society. Most national governments of the continent broadly supported higher education for the same reasons.

This period since 1999-2000 has been one of unprecedented, remarkable development of higher education in Europe (Matei et al. 2018; Scott 2012; Vögtle and Martens 2014). Until recently, higher education thrived in many regards almost everywhere on the continent, supported by the strong policy narratives of the European construction and knowledge societies. The two narratives together called for better-integrated societies, with higher economic competitiveness, better employment landscape, and social cohesion (Matei 2015). This unprecedented flourishing of higher education in Europe was also made possible by what looked like a triumphal March of democracy, started with the fall of the communist regimes of the East after 1989. Democratic expansions on the continent created a favourable milieu for higher education. At the same time, it was a common belief that higher education, in turn, can and must contribute to the advancement of democracy.

The buzzwords that mattered most for higher education and higher education policy during all this time were democracy, Europe, social cohesion, economic development, and jobs. This is what made the Bologna Process and the European 
Higher Education Area possible. This is why almost all European countries supported higher education and promoted their own reforms in the sector, including in the area of governance. This is how the "soul" of the university was understood and defined: the university's mission, or "soul", was to educate and produce knowledge that would support economically competitive and democratic European countries. Another EU Commission document is a good illustration for this understanding:

Universities have the potential to play a vital role in the Lisbon objective to equip Europe with the skills and competences necessary to succeed in a globalized, knowledge-based economy. (European Union 2006, p. 6)

As it will be discussed below, significant developments in governance and funding have taken place linked to this particular understanding of how universities could or should contribute to the overarching objectives and projects of this period at the European level, as well as nationally.

Now, times are changing, and these changes are having on impact on higher education. In many places where democracy was a genuine commitment not just a slogan, and democratic progress a reality not just discourse, we now witness authoritarianism, populism, or what is called with cynical self-flattery "illiberal democracy" (Rupnik 2017). Where we used to hear talk about Europe, we now hear Brexit and governments calling to "stop Brussels", 4 even in countries whose citizens had earlier voted in referenda to join the EU. Where we used to hear about policies seeking economic advancement, social solidarity and shared benefits from economic developments, now we hear almost open talk about institutionalised corruption at the state level, captive states or even of mafia states (Harding 2011).

Another significant recent development outside the sector, which brings new challenges, including for governance and funding, has to do with increased migratory fluxes and an escalating refugee crisis in Europe, with huge political, social, and economic implications, beyond innumerable individual tragedies. We are only starting to take the measure of the direct and indirect impact on higher education of this phenomenon.

How will these broader developments taking place outside higher education influence its future on the continent? This requires reflection and research. Will the support for higher education diminish in the years to come in Europe? Will higher education become less central to the European experience, possibly even peripheral in some countries?

These emerging trends are not happening equally in all parts of Europe. European organisations such as the EU and the Council of Europe remain committed to the knowledge society narrative, democracy and, at least in some way, to the European integration - and thus to supporting higher education. Many governments, in different ways, continue to act nationally, based on the conviction that higher education is indeed something to be treasured and nurtured, and that it must

\footnotetext{
${ }^{4}$ See https://ec.europa.eu/commission/publications/stop-brussels-european-commission-respondshungarian-national-consultation_en (accessed on 15 December 2017) for the answer of the EU Commission to the "Stop Brussels" campaign in Hungary.
} 
remain a key matter for public policy. But even in some of those countries, times seem to be changing. Germany, for example, remains one of the champions of betting on higher education to sustain its economic and social model and high standards of living. Newly emerging political forces, however, are at least sceptical about higher education, and many in the country are beginning to realise that. If these new forces, sceptical of higher education, accede to power, how would that play out for higher education in Germany ${ }^{5}$ ? Will Germany become like Hungary where the government declared officially that higher education is an unnecessary luxury, to be dispensed of (Matthews 2017)?

\section{Main Evolutions in the Governance and Funding of Higher Education Since the Start of the Bologna Process and the Launch of the EHEA. Current Challenges and Possible New Evolution Trajectories}

The broader European evolutions of the last 20 years sketched above had an impact on governance and funding in higher education, at the European, national, and institutional level:

- The EHEA, as a new space for dialogue and practice in higher education, is also a new, sui generis type of entity, or system, that requires and indeed has developed new governance - that is, new governance concepts, principles, models, tools and practices (Matei and Iwinska in this volume).

- One of the most original, important and influential new developments in governance, at the European level, is the so-called "open method of coordination" (OMC). ${ }^{6}$ The OMC is used not only for, by, and within the European Unionwhere it emerged as a governance principle and tool for the broader Lisbon strategy based on intergovernmental voluntary cooperation and soft low, but for the entire Bologna Process as well (Veiga and Amaral 2006). This governance method became a reference and model for initiatives aiming at regional integration in higher education in other parts of the world as well (Teodoro and Guilherme 2014).

- Funding of higher education has not been an official action line of the Bologna Process and in the EHEA. This was identified as a major "policy gap" (Matei 2012). However, transnational concepts, policy frameworks, as well as actual European-wide funding initiatives have emerged, promoted primarily, if not exclusively, by the European Union and subsumed to broader European

\footnotetext{
${ }^{5}$ These were comments made by participants on the margin of the 2017 Die Zeit Conference on University \& Education, in response to a presentation on dangers for universities in Europe; see https://www.ceu.edu/node/20520. Accessed on 15 January 2018.

${ }^{6} \mathrm{http} / / /$ ec.europa.eu/invest-in-research/coordination/coordination01_en.htm\#1. Accessed on 5 January 2018.
} 
agendas. Talking about "the power of the purse", Batory and Lindstrom (2011) point at one of the most important and subtle examples of using funding as a steering tool at the European level: how the EU funding for joint transnational degrees has a far reaching impact on the national regulatory frameworks for higher education. At the national level, during this period, we have witnessed many waves of reforms of the funding of higher education, as systematically documented by the Public Funding Observatory, ${ }^{7}$ a European-wide monitoring initiative of the European University Association.

- Significant evolutions can be noted in particular areas or aspects of university governance, such as academic freedom and university autonomy. An analytic summary of these evolutions is presented in another section of this volume (Matei and Iwinska in this volume). As part of the advent of the European Higher Education Area, we have witnessed the emergence of a European notion of university autonomy, which has become a consequential reference and model within Europe and globally. We can track back this development directly to the broader political endeavour of building a knowledge society in the European Union, or even for the entire European continent. A European notion of autonomy has emerged based on some kind of European consensus regarding the need for universities to acquire more institutional freedoms so that, in turn, they could be more efficient in delivering the types of services and goods deemed necessary for the advancement of defined European and national policy goals. Many national governments have also promoted reforms in the area of university autonomy (Matei, Iwinska in this volume). Until recently, most of these reforms have been meant to support increased autonomy, at least in certain dimensions, which in turn was expected to support more efficient work of the university, as judged against pre-set criteria defined by the public authorities.

- In the same area of autonomy, however, we witness a reverse trend currently in some countries, along with new developments in the society at large. Some governments have begun restricting autonomy openly. Kováts (in the governance section of this volume) discusses the case of Hungary where constitutional restrictions on autonomy and academic freedom have been imposed after 2010-2013, and the introduction of the chancellor system appears to restrict further, organisationally and operationally, the autonomy of the universities in the country. Two papers in this section discuss other aspects of university autonomy in Europe. The first one is about the Autonomy Scorecard, the latest exercise of monitoring university autonomy covering about 20 systems in Europe (Pruvot and Estermann, in this volume). This paper points to diverging trends in different countries and parts of Europe. A second paper looks at the validity of the concept and methodology on which this important and unprecedented monitoring exercise, first started in 2009-2010, is based (Orosz in this volume).

\footnotetext{
${ }^{7}$ http://www.eua.be/activities-services/projects/eua-online-tools/public-funding-observatory-tool. aspx. Accessed on 5 January 2018.
} 
- Overarching European dynamics and objectives have contributed to European-level developments in governance. These, in turn, have sometimes played a role in triggering national or regional reforms or policy initiatives. The mechanisms by which European principles are translated at the national level involves policy learning, an important characteristic and process in the EHEA. Two such cases are discussed in the present section. Curaj and Holeab (in this volume) examine policy learning in higher education under the umbrella of the EHEA more generally in Romania and in university governance in particular. Toderas and Stavaru (in this volume) discuss the impact of the European processes in the governance of the higher education systems of the Eastern Partnership countries (Armenia, Azerbaijan, Belarus, Georgia, Moldova ad Ukraine), looking in particular at the development of public accountability regulations and practices. We may ask whether such processes will be weakened in this part of Europe, and possibly even reversed if the broader European outlook is changed.

- A key policy concern that influenced the evolution of governance and funding was about efficiency. Efficient, or "more efficient" universities was a mantra of this entire period and it remains so. But what is efficiency in the university? A project coordinated by the European University Association (EUA) seems to point out that the concept of efficiency is not only vague in Europe (and elsewhere) but that it basically lacks a clear definition altogether. ${ }^{8}$ Its operationalisation and measurement are almost always unconvincing (Kupryianova et al. in this volume). Surprisingly, the same paper shows that there is almost no research on efficiency in the university either. The paper presents the work of an EUA-led team project towards developing a definition and inventorying good practices in efficiency in university in Europe. Another paper in the governance section (Jongbloed et al. in this volume) looks at policy initiatives that bring about new funding tools and principles (performance-contracts based funding), with new understandings of autonomy and efficiency in universities.

\section{Conclusions}

In light of both ongoing and newly emerging developments in Europe that are expected to influence the course of higher education in the immediate future in the area of governance and funding, in particular, several important questions appear to need to be asked:

\footnotetext{
${ }^{8}$ EUSTREAM: Universities for Strategic, Efficient, and Autonomous Management, described at http://www.eua.be/activities-services/projects/current-projects/governance-funding-public-policy/ ustream. Accessed on 5 January 2018.
} 
- What is the future of the European Higher Education Area now that the European integration process is stalled, or perhaps reversed?

- Should the EHEA continue after Brexit? Is that even possible? Will it remain the same? How can this be done?

- Where should the European leadership come from in these times of changes and uncertainty?

- What do governments, the public and those working in higher education themselves need to know about the changing narratives and other societal transformations that are already or will affect higher education? What should we tell them, as researchers?

- How should higher education institutions position themselves in times of changing policy narratives and regression of democracy? This question does not apply in the same way to higher education institutions in all European countries. Some of them are already under severe pressure, some others less so or not at all. It is still an important question, whether we are asking about universities in Turkey (some of which were closed down, what can they do?), in Hungary (where autonomy has all but evaporated already), in Germany, in the UK, or in other countries of Europe.

In search for answers, the papers in this section on governance and funding look both at new and continuing developments. They look at governance and funding as:

- tools for steering in the hands of the government;

- tools for the higher education institutions themselves to go about their business;

- in the case of governance, as a defining characteristic of higher education institutions related to values, principles and institutional identity that needs to be understood and promoted beyond being a simple operational principle or tool.

Many have stated recently that ours is a time for soul-searching in higher education and higher education policy (see for example Finn 2018, in "British Universities in the Brexit Moment"). Reflection and action on governance and funding remain crucial to this exercise.

\section{References}

Batory, A., \& Lindstrom, N. (2011). The power of the purse: Supranational entrepreneurship, financial incentives, and European higher education policy. Governance, 24(2), 311-329.

Docking, J. R., \& Curton, C. C. (2015). Crisis in higher education: A plan to save small Liberal Arts Colleges in America. East Lansing: Michigan State University Press.

European Union. (2000). Presidency Conclusions Lisbon European Council, 23 and 24 March, 2000. Retrieved January 5, 2018, from http://www.europarl.europaeu/summits/lis1_en.htm.

European Union. (2006). Delivering on the modernisation agenda for Universities: Education, research, and innovation. Communication from the Commission to the Council and the European Parliament. Brussels, 10.5.2006. COM (2006) 208 final.

Finn, M. (2018). British Universities in the Brexit Moment: Political. Economic and Cultural Implications: Emerald Group Publishing. 
Grubb, W. N., \& Lazerson, M. (2004). The Education Gospel. The Economic Power of Schooling: Harvard University Press.

Harding, L. (2011). Mafia State: How one reporter became an enemy of the Brutal New Russia. Guardian Books.

Lewis, H. R. (2006). Excellence without a Soul: Does liberal education have a future?. New York: Public Affairs.

Matei, L. (2012). A policy gap: Financing in the European higher education area. In A. Curaj, P. Scott, L. Vlasceanu, \& L. Wilson (Eds.), European higher education at the crossroads: Between the Bologna process and national reforms (pp. 553-572). Dordrecht, Heidelberg, New York: Springer.

Matei, L. (2015). The future of higher education and "the European level. In A. Curaj, L. Matei, R. Pricopie, J. Salmi, \& P. Scott (Eds.), The European Higher Education Area: Between critical reflections and future policies. Heilderberg. New York, London: Springer International Publishing.

Matei, L., Craciun, D., \& Torotcoi, S. (2018). A resounding success or downright failure? Understanding policy transfer within the Bologna Process in Central and Eastern Europe. In A. Batory, A. Cartwright, \& D. Stone (Eds.), Policy Experiments failures and innovations beyond accession in Central and Eastern Europe. UK: Edward Eldgar Publishing.

Matthews, D. (2017). Orbán's risky strategy of attacking higher education. Times Higher Education, 8/24/2017(2320), 31.

Mbeki, T. (2004a). Lecture by the President of South Africa, Thabo Mbeki, at the Association of Commonwealth Universities/Mandela Rhodes Foundation and the African leadership Award. University of Cape Town, 4 November 2004. Retrieved April 1, 2007, from http://www.infor. gov.za/speeches/2004/04110909451001.htm.

Mbeki, T. (2004b). Our wisdom is a seedbed for a new era of hope. The Times Higher Education Supplement, 11/12/2004(1666), 12.

Rupnik, J. (2017). The illiberal democracy in Central Europe. Esprit, 6, 69-85.

Scott, P. (1998). The end of the European university? European Review, 6(4), 441-457.

Scott, P. (2012). The Bologna Process has been key to European universities' success. Guardian. Retrieved July 1, 2016, from http://www.theguardiancom/education//apr/30/bolognaprocesskey-european-university-success.

Teodoro, A., \& Guilherme, M. (Eds.). (2014). European and Latin American Higher Education between Mirrors. Rotterdam, Boston, Taipei: Sense Publishers.

Veiga, A., \& Amaral, A. (2006). The open method of coordination and the implementation of the Bologna process. Tertiary Education and Management, December 2006, 12(4), 283-295.

Vögtle, E. M., \& Martens, K. (2014). The Bologna Process as a template for transnational policy coordination. Policy Studies, 35(3), 246-263.

Open Access This chapter is licensed under the terms of the Creative Commons Attribution 4.0 International License (http://creativecommons.org/licenses/by/4.0/), which permits use, sharing, adaptation, distribution and reproduction in any medium or format, as long as you give appropriate credit to the original author(s) and the source, provide a link to the Creative Commons license and indicate if changes were made.

The images or other third party material in this chapter are included in the chapter's Creative Commons license, unless indicated otherwise in a credit line to the material. If material is not included in the chapter's Creative Commons license and your intended use is not permitted by statutory regulation or exceeds the permitted use, you will need to obtain permission directly from the copyright holder. 